\title{
World Bank's Smart Economics for Gender Equality: An Exposition
}

\author{
Varalakshmi M. ${ }^{1, *}$, Manjusree Naidu K. ${ }^{2}$ \\ ${ }^{1}$ Centre for Gandhian Studies, GITAM Institute of Management, GITAM University, India \\ ${ }^{2}$ Department of Entrepreneurship, GITAM Institute of Management, GITAM University, India
}

Copyright (C) 2014 Horizon Research Publishing All rights reserved.

\begin{abstract}
Gender empowerment, in terms of economic empowerment, played a significant role since historical times in upbringing of children, education of children and decision making; also it took care of widowhood and old age of women. Women with economic entitlement earned more respect and security than women without any such economic asset. While empowerment through education is the best way to empower women, economic empowerment certainly plays a difference in the quality of lives of women; especially illiterate, poor and women suffering with various types of ill treatment from domestic front and outside the home. In this context World Bank's Plan as Smart Economics: Gender Action Plan (2007-2010) came out with an objective to support women and girls to reach the main stream through its studies and support. The objective of the third goal of the "UN Millennium Development Goals" too, is for Gender equality and empowerment. How far we achieved this goal since its inception? It is in this context the present paper discusses the World Bank's Plan on Smart Economics; its concept; features and further considerations.
\end{abstract}

Keywords Women, Empowerment, Gender Action Plan (GAP), World Bank, Smart Economics and Women's Economic Participation

\section{Introduction}

When compared with yester years women are far ahead in terms of health; education and empowerment in many ways. But we should not be satisfied with the success so far. Hence World Bank considering the economic backwardness for women and the significance of economic returns both for women and the nations came out with this plan. Further, with an objective to "advance women's economic empowerment in the world Bank Group's client countries in order to promote shared growth and accelerate the implementation of Millennium Development Goal 3 (MDG-3 - promoting gender equality and women's empowerment)" (World Bank, September, 2006)[1], this Gender Action Plan (GAP)
2007-2010 came out" as "Gender Equality as Smart Economics". "Smart Economics" is to empower women in developing countries that "not only gives jobs and help them to economic growth" but also to pave a "route to combat poverty and a movement towards greater liberty and democracy" (Laine, 2010)[2].

Gender Action Plan (GAP) 2007-2010 aimed to invest for women's improvement in terms of, access to jobs, land rights, financial services, and agricultural inputs and infra-structure. Further, increased women's labour force participation is associated with reduced poverty and faster growth. Thus GAP also focuses on girl's transition from school that would benefit children and society as a whole. The four focussed areas in this plan are: energy, transport, and water and sanitation (World Bank web link )[3].

This plan came out, also due to World Bank's previous monitoring process on Bank's 2001- Gender Mainstreaming strategy. This research revealed a steady improvement in country's lending operations and technical assistance (World Bank, 2002 cited, World Bank, 2006)[1]. Further, research by Poverty Reduction and Economic Management Gender and Development Unit (PREMGE) held that during Fiscal Year 2004 and Fiscal Year 2005, ninety percent of World Bank projects in health and education sectors incorporated gender issues. At the same time World Bank's achievements in terms of promoting women's economic participation; in strengthening institutions to collect sex-disaggregated data and in measuring disaggregated results of its intervention were found to be less satisfactory; also overall economic progress is less robust (World Bank, March,2006, cited, World Bank, September, 2006)[1]. World Bank (September, 2006)[1] also refers elsewhere too on World Bank's commitments to improve sex-disaggregated statistics on cross-country data on women's economic participation; as for instance on women's participation in informal employment are notably weak (Millennium Project, 2003, cited). Considering all these, the World Bank group thought that it needs to strengthen the integration of gender issues in economic sectors where it has a comparative advantage. 


\begin{tabular}{|c|c|c|}
\hline & $\begin{array}{c}\text { Policy Level } \\
\text { Making Markets work for women }\end{array}$ & $\begin{array}{l}\text { Agency Level } \\
\text { Empowering women to compete in Markets }\end{array}$ \\
\hline Product Market & $\begin{array}{l}\text { - Reductionin monetary costs } \\
\text { - } \quad \text { Female-owned business } \\
\text { - Information to suppliers }\end{array}$ & $\begin{array}{ll}\text { - } & \text { Access to Information \&communication } \\
& \text { Technologies(ICTs) } \\
\text { - } & \text { Quality day care service } \\
\text { - } & \text { Business start-up grants } \\
\end{array}$ \\
\hline Financial Market & $\begin{array}{ll}- & \text { Reform financial institutions } \\
- & \text { Reform laws regarding right to own } \\
& \text { property } \\
\end{array}$ & $\begin{array}{ll}\text { - } & \text { Support Self Help Groups (SHGs)\& Rotating } \\
\text { Saving and Credit Associations (ROSCAs) } \\
\text { - } & \text { Gender sensitive business services } \\
\end{array}$ \\
\hline Land Markets & $\begin{array}{l}\text { - } \quad \text { Promote joint titling } \\
\text { Reform laws restricting women's } \\
\text { right to own land }\end{array}$ & $\begin{array}{l}\text { Ensure women's participation in land } \\
\text { adjudication and registration process } \\
\text { - Involve women in local and natural resource } \\
\text { management }\end{array}$ \\
\hline Labour Market & $\begin{array}{ll}\text { - } & \text { Introduce legislation to promote } \\
\text { women's employment } \\
\text { - } & \text { Socialize costs of maternity leave } \\
\text { - } & \text { Certify good gender practices } \\
\end{array}$ & $\begin{array}{l}\text { - Increase access to women's training } \\
\text { programmes } \\
\text { - Provision for labour intermediate services(to } \\
\text { migrants) }\end{array}$ \\
\hline
\end{tabular}

Figure 1. Plan Enhances Women's Empowerment

\section{Major Features of the Gender Action Plan (Fiscal Years 2007 - 2010):}

The Gender Action Plan (GAP) defines a concrete road map for four-years and it has actually come out to complement the existing main stream strategy on women empowerment with a view to further advancement. The flowing is a brief account of the major features and plans of GAP based on the World Bank's Gender Action Plan (September, World Bank, 2006)[1].

\section{Guiding Principles of GAP (2007-2010):}

The plan was focussed on selected countries and areas; tailored to individual country needs; grounded in empirical evidence on gender inequalities and oriented to results processes, outcomes and impacts. Other aspects include, focusing on building and replicating success and considering incentives rather than mandates and obligations. Finally it is designed to promote development effectiveness and to be aligned with Paris Declaration (this is endorsed on March 2, 2005 to commit more than 200 countries and development organizations to continue and increase efforts in harmonization, alignment, and managing aid for results with a set of monitorable actions and indicators, World Bank, September, 2006, see foot note 11).

\section{Targets of Action Plan:}

The Action Plan targets four key markets to empower women to compete in. These are: land, labour, product, and financial including formal and informal markets. This process reduces transaction costs by providing infrastructure investments which in turn increase women's access to these markets. While some of the action plans are operated through policy level by Bank Groups others are executed at agency level together contributing for women empowerment (see Figure 1, edited Figure 1 from World Bank, September, 2006)[1].

\section{Of Selected Areas and Countries:}

Africa, East Asia and the Pacific; Europe and Central Asia; Latin America and North Africa are the areas. The list of the possible countries preliminarily included Afghanistan, Cambodia, Ethiopia, Ghana; Honduras' Kenya; Lao PDR; Malawi; Mauritania; Mongolia; Mozambique; Niger; Papua New Guinea, Senegal; Tajikistan; Timor-Leste; Uganda; Vietnam and Yemen are from low income countries. From fragile states, Liberia; Sierra Leone and Sudan and from Middle-income countries, Armenia; Chile; China; Egypt; Guatemala; Indonesia; Morocco; Nicaragua; Philippines and Uruguay are selected.

\section{Major Action areas and Objectives:}

Action 1: Aimed to intensify gender mainstreaming in Bank and International Finance Corporation (IFC) and in key regional economic and social sector work. This action seeks to harness the opportunities by gender mainstreaming in infrastructure: energy, transport, mining, ICT, water and sanitation. This plan proposed to engender key Economic and Sector work such as, climate assessments; integrated poverty, social and gender assessments. Performance indicators include increase in number of female entrepreneurs; increase in application of gender analysis in land administration and quality of agriculture projects and water-projects that address gender differences and gender analyses.

Action 2: Through this action resources are mobilized and Result-Based Initiatives (RBIs) and other initiatives are implemented through Development Grant Facility (DGF) especially to low income countries. Some examples for RBIs are: policy reforms in agriculture that affect women's crops or women's access to land titling; promotion of female labour participation through incentives to private firms and job training programmes for women. Programmes such as provision of low-cost renewable energy to promote off-farm employment of women and facilitating formation of farmers' cooperatives and water users associations are some other RBIs.

Action 3: This action is meant to improve knowledge and statistics on women's economic participation and the relationship between gender equality, growth, and poverty reduction. This action deals with studies on World Bank's commitments in policy research on women's economic 
empowerment. Some of the areas of research are: micro foundations of gender equity and growth; macro links between gender equality and growth; funds for extra-mural research on economic empowerment of women. This plan also works through Development Economics Data Group (DECDG) which in turn works with International Labour Organization (ILO) and United Nations Economic Commission for Europe (UNECE) to improve gender statistics.

Action 4: This action is aimed to undertake targeted communication campaign and training to build partnerships on the importance of women's economic contribution and execute action plan. These actions include partnerships with donor countries in public launch to increase awareness of the Action plan; preparation of announcements on kiosk [booth]. Performance indicators include, increase in the number of development partners/clients; NGO intervention and others.

\section{Method of Monitoring and evaluation:}

This includes tracking the activities and measuring their results. It is through baseline assessments, mid-term reviews and other ways by assessing women's economic empowerment evaluation takes place. PRMGE's annual report and evaluation of RBI's by International Centre for Research on Women (ICRW) are some bodies that conduct evaluation (World Bank, September, 2006)[1].

\section{Human Resource:}

World Bank group took in to consideration that institutional capacity would be increased by employing an approach that emphasizes on results and "learning-by-doing-with-monitoring" approach ((World Bank, September, 2006). Further it also planned that staffing constraints would be addressed in two ways: by training staff to build up their capacity in gender issues and by hiring qualified consultants.

Financing: While initial planning by group estimated about \$24.5 million for the financial year 2007-2010; recent sources also held that the $\$ 63$ million with the budget support from external partners; including the governments of Australia, Canada, Denmark, Germany, Iceland, Norway, Spain, Sweden, Italy, the United Kingdom as well as the Nike Foundation to empower women economically [1].

\section{Self-assessment of performance of World Bank's GAP:}

The following is a brief account of Bank Group's self-assessment:

- Promoted Gender equality in developing countries through lending grants, knowledge, and analysis and policy dialogue.

- Total share of lending rose from 83 to 98 percent (from Financial Year (FY) 2012 to FY2013) that means US \$ 31 billion in FY 2013.

- 93 percent of operation in fragile and conflict countries was gender informed.

- World Bank staff who had never worked on gender was encouraged to include gender into their projects which resulted into evidence base of innovations, evaluation and research data (World Bank, October, 11, 2013)[4].

\section{Significance and Opinions on Smart Economics}

World of women in particular and general development groups internationally were appreciative of smart economics in many senses. Women are still working as unpaid family labourers and in small farm plots with less profitable crops and thus World Bank focussed on gender equality particularly on the economics of Gender.

Michelle Bachelet (2011)[5], UN women Executive Director, who was also as defence minister, an epidemiologist and a pediatrician and one who introduced several programmes for women and who widened health insurance provisions and held several positions and promoted female participation in Government expressed her grief: "With the recent global downturn women's economic position has further deteriorated, especially for the 53 percent of working women -600 million in total - who were in vulnerable jobs. Also there exists a huge gender gap - in practice, women are still paid 30 less than men in some countries. In terms of decision-making, only 28 countries have legislature where women make up at least 30 percent of the members, which is considered a critical mass for women in parliament. Women also continue to be in the frontlines of wars - even after peace has been declared. From Nepal to Afghanistan to Sudan, war harms women in multiple ways: from mass rapes to mass displacements". Therefore, she added, "Productivity gains from ensuring equal access to fertilizers, seeds and tools for women could reduce the number of hungry people by between 100 and 150 million".

When asked on needs to be done to shake the apparent hold of men over the levels of power in business world, Bachelet said that UN women have been working closely with private sector mostly in Latin America and in Egypt to promote Gender Equality seal which is certification process verifying whether a company meets standard that promote workplace equality. She cites countries like Norway where proactive policies were implemented by showing at least 40 percent requirements for representation of each sex in the boards.

Rodriguez (2011)[6], a programme officer for the Asia Foundation's women Empowerment Programme assessed World Development Report: "Gender equality as smart economics" has become the recent mantra of such women as Hillary Clinton and Michelle Bachelet. She also refers to Isobel Coleman from Council on Foreign Relations: "The Bank's framing of gender equality not only as a development objective in its own right, but also a smart economics, is an important message for those countries that lag the most on gender equality. Just as investing in women and girls can create a positive development cycle, the opposite is also true; countries that fail to empower half their population will suffer from lower productivity, slower economic growth, and 
weaker development outcomes".

Similarly Mary Okumu (2010)[7] reports on meeting at Johannesburg on Gender-Response Budgeting (GRB), which was actually made by the African Governments to scale-up GRB initiatives during the side-event organized by UNDP at $54^{\text {th }}$ session of the Commission on the Status of women held in 2010. It is reported: "Gender-Response Budgeting (GRB) is "Smart Economics, that reverberated them echoed during the three day's meeting ...”. In that meeting Nomcebo Manzini, the Regional Programme Director of UN women for Southern Africa came out with such facts that there are only four years away to meet the MDGs and that Sierra Leone government abolished the user fees at hospitals for women to increase health access and pre and post natal services which isa notable achievement

Similarly Laine (2010)[2] while speaking of challenges for smart economics policy, referred to world economic crisis in developing countries when many customers to micro-fiancé institutions were unable to repay their loans and raise new capital.

Zuckerman (2007)[8] opines that while GAP's objective was to make markets work for women it is critically important that it fully ignores the moral imperative of empowering women to achieve women's human rights and full equal rights with men. For the world Bank ignores the most important argument that the main beneficiaries of infrastructure - agriculture, finance and infrastructure as transport, mining, information and communication technology, water and sanitation - all benefit corporations the most, but not poor men or women. Zuckerman also points out that the standard economic reforms that the bank imposes on poor countries - low-inflation and tight spending policies only sabotage MDG 1 that focuses on universal education and MDG 2 on young female health. Further the Bank never mentioned about its Multi Lateral Investment Guarantee agency (MIGA) which constantly guarantees corporate investments with extremely harmful gendered impacts.

\section{For Furtherance}

In one way, Gender equality in the world of work is a win-win of many forms. As per Booz \& company (cited.) estimates raising female participation have a direct impact on GDP increasing 34 percent in Egypt; 12 percent in United Arab Emirates; 10 \% in South Africa and 9 percent in Japan. On the other hand, ILO's estimates held, almost half of women's productive potential globally is unutilized compared to men's 22 percent (World Bank, 2014)[9]. A 2012 Credit Suisse study (cited) of nearly 2400 companies across the world found that the share prices of companies that have at least one woman on their boards perform 26 percent more than the companies that do not women.

Research data from by International Bank for Reconstruction and Development (IBRD) in combination with World Bank (2013)[10] finds that almost 90 percent of the 143 countries covered by women, business and the Law
2014 have at least one legal difference restricting women's economic opportunities.

While IBRD and World Development Report (2013) finds that jobs are broadly defined to include various forms of wage, non-wage, formal and informal. Informal work is the major source for of employment for women in Africa, Asia, and the Middle East. Bank recognises jobs that are best for women's economic empowerment. And development goals more broadly depend on country-specific jobs and challenges. And more important is, women's ability to make choices; to act on the choices and jobs can increase women's agency by expanding their life choices and their capacity to support their families and to actively participate in communities and societies.

\section{Concluding Remarks}

Attitude of people ultimately matters in terms of cooperation and understating and encouragement for girl child development. Further, adult woman's economic participation at familial level; inclusive attitude of civil society and protective and welfare laws from state level are welcoming signs for women's empowerment. As suggested by IBRD and World Bank, solutions for economic security or comprehensive development of women and young children can be country-specific. Thus it can be culture-based too; policy implementation would be strengthened when it is culturally too accepted by societies. Many women entrepreneurs are also running such business that caters the demands of high society people who have un-satiated demands to please their fashion and passion. Women in rural society and urban poor strata too are following these lines and entering such professions that are not actually conducive to the psychological environment of women at large. Rather awareness programme for literacy; psychological counselling for women on marriageable age and need for "learning while earning" to enter such professions as food making; candle and paper bags; soaps and detergents would help women economically in a better way.

\section{REFERENCES}

[1] World Bank (September, 2006). Gender Equality as Smart Economics: A World Bank Group Gender Action Plan (Fiscal Years 2007 - 2010). Availed from: http://siteresources.worldbank.org/INTGENDER/Resources/ GAPNov2.pdf

[2] Laine, Michael de (2010). Empowering Women in Developing Countries is "smart economics" but faces challenges in The Copenhagen Voice, 31, March, 2010. Availed from: http://cphvoice.ning.com/profiles/blogs/empo wering-women-in-developing

[3] Gender and Development: Gender Action Plan: Gender 
Equality as Smart Economics. Availed from: http://web.worldbank.org/WBSITE/EXTERNAL/TOPICS/E XTGENDER/0,,contentMDK:21983335 pagePK:210058 pi PK:210062 theSitePK:336868,00.html

[4] World Bank (October, 11, 2013). Gender Overview. Availed from: http://www.worldbank.org/en/topic/gender/overview

[5] Bachelet, Michelle (2011). Women's engagement is smart economics in Global the International Briefing. Availed from: http://www.global-briefing.org/2011/10/womens-engagemen t-in-economic-activity-at-all-levels-is-smart-economics/

[6] Rodriguez, Barbara (October5, 2011). 2012 World Bank Development Report: Gender Equality as Smart Economics in Weekly Insight and Analysis by Asia Foundation. Availed from: http://asiafoundation.org/in-asia/2011/10/05/2012-world-ban k-development-report-gender-equality-as-smart-economics/

[7] Okumu, Mary (2010). Gender Responsive Budgeting is Smart Economics in Social Accountability Platform for Africa by
SAP 4 Africa. Availed from: http://www.sap4africa.net/news /gender-responsive-budgeting-smart-economics

[8] Zuckerman, Elaine (January, 2007). Gender Action: Critique: Gender Action Plan: Gender Equality as Smart Economics. A World Bank Group Gender Action Plan (GAP) (Fiscal Years 2007-2010). Availed from: http://www.genderaction.org/ima ges/04.22.08_EZ-GAPlan\%20Critique.pdf

[9] World Bank (2014). Gender at Work: A companion to the World Development Report on Jobs [A Report prepared as a companion to WDR on Jobs, February, 20, 2014]. Availed from: http://www.worldbank.org/en/topic/gender/publication /gender-at-work-companion-report-to-world-development-re port-2013-jobs

[10] International Bank for Reconstruction and Development/World Bank (2013). Women, Business and the Law, 2014: Removing Restrictions to enhance Gender Equality. Availed from http://wbl.worldbank.org/ /media/FP DKM/WBL/Documents/Reports/2014/Women-Business-and -the-Law-2014-Key-Findings.pdf 